\title{
An Investigation into the Application of Educational Technology at Higher Educational Institutions
}

\author{
Samira Shah \\ Department of Education, Preston University, Islamabad, Pakistan \\ Email: sami10star@hotmail.com \\ Ali Murtaza \\ Institute of Education, University of Azad Jammu \& Kashmir, Muzaffarabad, Pakistan \\ Email: draliibd@gmail.com
}

\begin{abstract}
The title of the study was 'An Investigation into the Application of Educational Technology at Higher Educational Institutions'. The Objectives of the Study were to describe the nature and features of Educational Technology, to evaluate the role of Educational Technology in promoting comprehension learning, and suggest possible solutions to minimize the problems occurred in its application. The sample of the study consisted of Three hundred fifty prospective teacher of Bachelor in Education (B.Ed) in Higher Educational Institutions. Two separate questionnaires were prepared for both the students and the teachers of teachers training institutions. Appropriate statistics were used for the purpose of description, analysis and findings of the received data. Percentage of responses to each item was calculated. Overall mean score of each table was also calculated. The research showed that Educational Technology is significantly helpful to enhance the comprehension learning and motivation of the students. Modern trends in the use of Educational Technology are being developed rapidly at Higher Educational Institutions in Pakistan. Students stated that the teachers should use the modern tools of Educational Technology more. Students also believed that teachers should be well trained regarding the use of Educational Technology. Students said that more facilities may be provided to prospective students in terms of access to tools of Educational Technology. The teachers were also of the view that more Training in the application of educational technology tools should be provided, to improve their capability. The main recommendations of the study are that Educational Technology should be promoted, more facilities should be provided to students in terms of access to tools of Educational Technology. The all components of teaching practice in the Teacher Training Institutions should be well managed.
\end{abstract}

Index Terms — educational technology, prospective teachers, teacher training

\section{INTRODUCTION}

Educational Technology's history is traceable back to the end of the Second World War. At that time, Educational Technology emerged as a separate domain of its own. Since its beginning the Educational Technology has passed through three major stages, the first being 'Mass Instruction', second 'Individual learning' and third 'Group learning'. The first stage is concerned with the process of teaching a vast number of people simultaneously by a small number of instructors or trained teachers. Cost effectiveness was the principal target of using mass instruction. All the technical instruments used during that period were in order to provide education to maximum people in minimum time. Thus the use of close circuit camera (CCTV) became very rampant during that era. Over the years, Educational Technology has expanded with hardware. The second stage of Educational Technology was dominated by Individualized learning. Focusing on the concept that the learner should be actively involved in the learning process, the educational technologists and researchers started to devise a variety of individualized learning materials in the form of printed materials, slides, computer programmes, audio materials and models. This second stage was linked to software-suitable leaning materials. The third era of Educational Technology which is also the latest and most recent phase comprises the group learning techniques. The most famous methods used for group learning are as follows: brainstorming, group dynamics, simulations, interactive case studies etc.

Educational Technology in fact is defined as the usage of various types of modern methods, media and materials for increasing the learning and teaching experiences. It deals with the systematic application of the resources of scientific knowledge of the process that each individual has to pass through in order to acquire and use knowledge. Educational Technology can improve the comprehension of the learning process, as it delivers knowledge in a more lucid and concrete matter.

Educational technology is now widely valued for its ability to enhance one of the most significant intellectual developments for students: their emerging ability to think abstractly (Jarrett, 1998, p. 4). 
Rowntree (1988, p. 22) defined Educational Technology as systematic way of designing, carrying out and evaluating the total process of teaching and learning and communication and employing a combination of human and non-human resources to bring about more comprehensive instruction.

Hawkins (1996, p. 2) said that schools successfully integrate technology show a clear and meaningful connection between technology and larger educational goals and in promoting teaching. They also experimented on the vision of how technology can improve teaching and learning. Essential to this vision is an emphasis on meaningful and engaged learning with technology, in which students are actively involved in the learning process. Students take ownership of their learning, acting as explorers and producers; teachers function as facilitators and guides.

Technology, when used effectively can encourage collaborative learning, development of critical thinking skills, and problem solving (www.ceo.wa.edu). It can help learners to explore the world beyond the classroom by providing access to vast resources and information, promoting scientific inquiry and discovery, and allowing students to communicate with experts. Technology used for authentic tasks can provide students with opportunities to interact with a wealth of resources, materials, and data sets, and to perform challenging tasks similar to those in careers and out-of-school activities. Educational Technology will have the greatest impact on student learning when integrated into the curriculum to achieve clear, measurable educational objectives.

Russell (1997, P. 257) studied the effects of test administration mode to see whether tests administered on computer versus paper-and-pencil have an effect on student performance on multiple-choice and written test questions. The study found that significantly higher cognitive-level responses are written on computers than those written by hand.

Rochelle (2000, P. 2) identified four fundamental characteristics of how technology can enhance student leaning: (1) active engagement, (2) participation in groups, (3) frequent interaction and feedback, and (4) connections to real-world contexts. They also indicate that use of technology is more effective as a learning tool when embedded in a broader education reform movement that includes improvements in teacher training, curriculum, student assessment, and a school's capacity for change.

The educational role of technology has grown tremendously in several ways proving that technology use is undeniably capable of, and important for, helping in teaching process. Jarrett, (1998, p. 4) noted that: Educational technology is now widely valued for its ability to enhance one of the most significant intellectual developments for students: their emerging ability to think abstractly.

Fox (2005, p. 42) stated that" Educational Technology being infused into the schools is ongoing, unstoppable, and necessary. Thus, educational institutions use and access to new and current technologies is on the rise and more and more states have established technology standards for students, teachers, and administrators. Teachers have begun to use the Internet more frequently as a valuable tool in their instruction: Seventy-seven percent of public schools had a majority of teachers who used the Internet for instruction during the 2003-04 school year, up from 54 percent in 199899 ... with 73 percent of high-poverty schools and 71 percent of high-minority schools having a majority of their teachers using the Internet for instruction."

Waxman, (2002, P.1) studied the effects of teaching and learning with technology on student outcomes. This metaanalysis examined the data from 20 studies involving approximately 4,400 students. They found that teaching and learning with technology has a small, positive, significant effect on student outcomes compared to traditional instruction

Chickering (1996, pp. 144-145) stated that" the research findings of good practice in innovative educational technology-enhanced and educational technology-delivered education. They determined that there were at least seven factors as follows that were critical in manifesting effective good practice of educational technology use: Encouraged contacts between students and faculty, especially those students who were unwilling to speak out in face-to-face classroom settings, developed reciprocity and cooperation among students allowing for the benefits of peer learning, used active learning techniques that made students active learners, gave prompt feedback, emphasized time on task, communicated high expectations, respected diverse talents and ways of learning."

McCann, et. al.,(1998, pp. 17-18), stated that "one of the key benefits of educational technology is its positive role in overcoming problems of access to university study through providing more flexible opportunities for study." They also stated that according to Alexander and Taylor a key positive contribution the use of technology can bring to university teaching and learning is that it encourages teachers, educational designers and managers to ask questions about the way learning happens. The application and use of Educational Technology promotes study comprehension and interest in learning. McCann, et. al., (1998, P. 17) said that "Technologies offer major opportunities to higher education to enhance the quality, accessibility and cost effectiveness of university teaching. Electronic mail, computer conferencing, and the World Wide Web are strengthening contacts between students and academic staff. Technologies provide increased opportunities for interaction which can usefully provide for joint problem solving, shared learning and enhance face-toface contact." Higher education considered as productive education. All societies tried to provide all latest infrastructures in this sector which help to promote its quality as per social demands. With the turn of the century, the world has undergone a technology explosion and its use has remarkably increased in the Educational arena too. Due to the increased competition and grandiose challenges, the importance of Educational Technology has also become more important and pronounced. Increased attention is being given to how education is imparted and ways and measures are taken to improve the comprehension of learning. Educational Technology is contributing in improving the standard of education in a big way. Educational Technology and improved learning seems to be strongly connected. Educational 
Technology has become an effective and innovative practice which could be used by teachers in order to promote comprehension of learning.

There is an old byword that I hear, I forget; I see, I remember; I do, I understand. Educational Technology pertains to the third part of the byword as it actively involves the student in the learning process making it more comprehensive and concrete.

\section{EducAtional TeChNOLOGY \& Higher EduCATiON}

The use of Educational Technology has increased in Higher Educational Institutions. Most of the Higher Educational Institutions are providing their students with modern tools of Educational Technology. The typical lecture method has almost disappeared. Now teachers can use audio-visual aids, projectors, laptop, computers and multimedia to impart knowledge in a more easy $n$ flexible way. Online courses are available in bulk. Use of Educational Technology has made it possible for those who are keeping down a full time job to get degrees by accessing immense amount of knowledge through the online courses provided by the Higher Educational Institutions." The higher education system and institutions must accord higher priority to ensuring the quality of services and quality of outcomes. Internal quality assurance process of higher education institutions must be strengthened to confirm to international standard of quality assurance" (M.O.E, 2009, p.58) Educational Technology is now being practiced at all academic levels. Its importance cannot be denied in higher education. According to American Heritage Dictionary of the English Language (2009, P. 1), Higher Education is the Education beyond the secondary level, especially education at the college or university level.

According to Roblyer M.D (2008, p.8)," Educational Technology is a combination of processes and tools involved in addressing educational needs and problems, with an emphasis on applying the most current tools: computers and other electronic gadgets" Educational Technology attends to the problem faced by the teachers in imparting learning and by the students in acquiring knowledge. Student's basic needs are also catered by Educational Technology. Now students have access to more information and they can study anywhere. Teaching is no more classrooms limited.

\section{METHODOLOGY}

This study evaluated the application of Educational Technology by using Survey Method of Descriptive Research." Surveys may be used for descriptive, explanatory, and exploratory purposes. Survey research is probably the best method available to the social scientist interested in collecting original data for describing a population too large to observe directly"(Bubbie, E. 1998,p.256).

In order to investigate the application of Educational Technology in promoting learning comprehension, a purposive sample of both male and female prospective teachers selected randomly.

The data was collected from the Universities through the approved questionnaires. Percentage and mean score used to analyze the collected data through the two questionnaires of students and teachers. Conclusion drawn based on results of respondents.

A. Analysis of Data of Questionnaire for Students

Summary of the returned questionnaires (students) is given below:

\begin{tabular}{|l|l|l|l|l|}
\hline Population & Sample & Delivered & Received & \% Questionnaire Returned \\
\hline 350 & 350 & 350 & 346 & $99.1 \%$ \\
\hline
\end{tabular}

\begin{tabular}{|c|c|c|c|}
\hline \multicolumn{4}{|c|}{ Students Responses } \\
\hline S. No & Item & Yes & No \\
\hline 1 & Is Educational Technology taught in your study Programme? & $\begin{array}{l}97.0 \% \\
(336)\end{array}$ & $\begin{array}{l}3.0 \% \\
(10)\end{array}$ \\
\hline 2 & Is a white- board placed in your class room? & $\begin{array}{l}96.0 \% \\
(331)\end{array}$ & $\begin{array}{l}4.0 \% \\
(15)\end{array}$ \\
\hline 3 & $\begin{array}{l}\text { Is there any Educational Technology Resource Centre available at your } \\
\text { Institution? }\end{array}$ & $\begin{array}{l}86 \% \\
(299)\end{array}$ & $\begin{array}{l}14 \% \\
(47)\end{array}$ \\
\hline 4 & Is a computer provided to each student in the lab? & $\begin{array}{l}63 \% \\
(218)\end{array}$ & $\begin{array}{l}37 \% \\
(128)\end{array}$ \\
\hline 5 & Are you able to work on PowerPoint? & $\begin{array}{l}99 \% \\
(341)\end{array}$ & $\begin{array}{l}1 \% \\
(5)\end{array}$ \\
\hline 6 & Are You able to Works on MS office? & $\begin{array}{l}97 \% \\
(336)\end{array}$ & $\begin{array}{l}3 \% \\
(10)\end{array}$ \\
\hline 7 & Are you using Internet for your studies? & $\begin{array}{l}99 \% \\
(341)\end{array}$ & $\begin{array}{l}1 \% \\
(5)\end{array}$ \\
\hline 8 & $\begin{array}{l}\text { Have you ever attended a lecture through video or teleconferencing at your } \\
\text { Institution? }\end{array}$ & $\begin{array}{l}75 \% \\
(259)\end{array}$ & $\begin{array}{l}255 \\
(87)\end{array}$ \\
\hline 9 & Is internet facility available in your Institution? & $\begin{array}{l}97 \% \\
(336)\end{array}$ & $\begin{array}{l}3 \% \\
(10) \\
\end{array}$ \\
\hline
\end{tabular}

Table 1 show that $97.0 \%$ have agreed with the statement while $3.0 \%$ have not agreed. Hence, the statement, Is Educationnel Technologies taught in your study Programme? considered as accepted. 
Table 2 shows that $96.0 \%$ of the respondents have agreed with the statement while $4.0 \%$ have disagreed. Hence, the statement' Is a white- board placed in your class room?' is accepted.

Table 3 indicates that $86.0 \%$ have agreed with the statement while $14.0 \%$ have disagreed. Hence, the statement 'Is there any Educational Technology Resource Centre available at your Institution?? 'is accepted.

Table 4 shows that a huge majority of $63.0 \%$ has agreed with the statement while $37.0 \%$ were not of the same opinion. Hence, the statement 'Is a computer provided to each student in the lab?' is accepted.

Table 5 indicates that $99.0 \%$ have agreed with the statement that they are able to work on PowerPoint while $1.0 \%$ has disagreed. Thus, this statement "Are you able to work on PowerPoint? Is accepted

Table 6 shows that the majority of the respondents i.e. $97.0 \%$ have agreed that they could work on MS Office while $3.0 \%$ did not agree. Hence, the statement 'Are You able to Works on MS office??' is accepted.

Table 7 points out that $99.0 \%$ have agreed with the statement that they attended a lecture through video or teleconferencing order while $1.0 \%$ did not think the same. Hence, the statement' Are you using Internet for your studies?' is accepted.

Table 8 indicates that $75.0 \%$ have agreed with the statement that internet facility was available at their Institution while $25.0 \%$ have disagreed. The statement, have you ever attended a lecture through video or teleconferencing at your Institution? is accepted.

Table 9 indicates that $97.0 \%$ have agreed with the statement that internet facility was available at their Institution while $3.0 \%$ have disagreed. The statement is internet facility available in your Institution? is accepted.

\begin{tabular}{|l|l|l|l|l|l|l|l|}
\hline No & Statement & SA & A & UNC & DA & SDA & $\begin{array}{l}\text { M. } \\
\text { Score }\end{array}$ \\
\hline 1 & $\begin{array}{l}\text { Educational Technology helps in improving the } \\
\text { cognitive, affective and behavioral type of } \\
\text { learning }\end{array}$ & 161 & 175 & 9 & 1 & - & 4.3 \\
\hline 2 & $\begin{array}{l}\text { Educational tools like computers, multimedia and } \\
\text { projectors have become very common in learning } \\
\text { at Higher Educational Institutions. }\end{array}$ & 136 & 199 & 3 & 7 & 1 & $\mathbf{4 . 2}$ \\
\hline 3 & $\begin{array}{l}\text { Opportunity in the use of tools of Educational } \\
\text { Technology is provided to every student. }\end{array}$ & 76 & 178 & 16 & 69 & 7 & 3.7 \\
\hline 4 & $\begin{array}{l}\text { Mostly teachers are well aware with the use of } \\
\text { Educational Technology }\end{array}$ & 63 & 177 & 20 & 84 & 2 & 3.6 \\
\hline 5 & $\begin{array}{l}\text { Management is very optimistic in the use of } \\
\text { modern trends of E.T towards their pupil teachers }\end{array}$ & 74 & 205 & 31 & 34 & 2 & 3.8 \\
\hline 6 & $\begin{array}{l}\text { Educational Technology is playing very effective } \\
\text { role in promoting students confidence }\end{array}$ & 130 & 206 & 6 & 2 & 2 & 4.6 \\
\hline 7 & $\begin{array}{l}\text { Educational Technology helps in increasing } \\
\text { comprehension of the students }\end{array}$ & 157 & 184 & 5 & - & - & 4.3 \\
\hline 8 & $\begin{array}{l}\text { The use of Educational Technology helps in } \\
\text { increasing the interest and motivation of the } \\
\text { students }\end{array}$ & 183 & 158 & 4 & 1 & - & 3.7 \\
\hline 9 & $\begin{array}{l}\text { The use of Educational Technology helps to } \\
\text { improve the scientific approach and technological } \\
\text { application in learning }\end{array}$ & 193 & 144 & 8 & 1 & - & 4.4 \\
\hline 10 & $\begin{array}{l}\text { Educational Technology helps to increase } \\
\text { student's overall academic performance and } \\
\text { confidence level }\end{array}$ & 192 & 148 & 1 & 4 & 1 & 4.4 \\
\hline 11 & $\begin{array}{l}\text { Educational Technology is playing a leading role } \\
\text { changing the study habits of the students }\end{array}$ & 195 & 139 & 10 & 2 & - & 4.4 \\
\hline 12 & $\begin{array}{l}\text { The use of Educational Technology is increasing } \\
\text { day by day at your Institution }\end{array}$ & 154 & 135 & 15 & 35 & 7 & 4.0 \\
\hline
\end{tabular}

Table 1 Illustrates that $97 \%$ have agreed that Educational Technology improves the cognitive, affective and behavioral type of learning while $1.0 \%$ has disagreed. $3.0 \%$ remained undecided. The mean score 4.3 falls in the level of agreement which supported the statement 'Educational Technology helps in improving the cognitive, affective and behavioral type of learning'. Hence, the statement is accepted.

Table 2 indicates that $96.0 \%$ have agreed that use of projectors and multimedia is increasing at the Higher Educational Institutes while $3.0 \%$ have disagreed. 1.0\% was undecided. The mean score 4.2 falls in the level of agreement which supported the statement 'Educational tools like computers, multimedia and projectors have become very common in learning at Higher Educational Institutions'. Hence, the statement is accepted.

Table 3 points out that $73.0 \%$ have agreed with the statement while $22.0 \%$ have disagreed. $5.0 \%$ were uncertain. The mean score 3.7 falls in the level of agreement which supported the statement, Opportunity in the use of tools of Educational Technology is provided to every student.' Hence, the statement is accepted.

Table 4 shows that $69.0 \%$ have agreed with the statement while $25.0 \%$ have disagreed. $6.0 \%$ remained undecided. The mean score 3.6 falls in the level of agreement which supported the statement "Mostly teachers are well aware with the use of Educational Technology" Hence, the statement is accepted.

Table 5 indicates that $80.0 \%$ have agreed with the statement while $11.0 \%$ have disagreed. $9.0 \%$ were undecided. The 
mean score 3.8 falls in the level of agreement which supported the statement 'Management is very optimistic in the use of modern trends of E.T towards their pupil teachers'. Hence, the statement is accepted.

Table 6 indicates that $96.0 \%$ have agreed with the statement while $2.0 \%$ have disagreed. $2.0 \%$ was undecided. The mean score 4.2 falls in the level of agreement which supported the statement 'Educational Technology is playing very effective role in promoting students confidence'. Hence, the statement is accepted

Table 7 indicates that $99.0 \%$ have agreed with the statement while 0 percent has disagreed. $1.0 \%$ was undecided. The mean score 4.3 falls in the level of agreement which supported the statement 'Educational Technology helps in increasing comprehension of the student'. Hence, the statement is accepted

Table 8 illustrates that a huge majority of $98.0 \%$ have agreed with the statement while $1.0 \%$ has disagreed. $1.0 \%$ was undecided. The mean score 3.7 range in the level of agreement which supported the statement 'The use of Educational Technology helps in increasing the interest and motivation of the students'. Hence, the statement is accepted

Table 9 shows that $97.0 \%$ of the respondents thought that the importance of Educational Technology is especially pronounced to ameliorate the scientific approach while $1.0 \%$ have disagreed. $2.0 \%$ was undecided. The mean score 4.4 falls in the level of agreement which supported the statement "The use of Educational Technology helps to improve the scientific approach and technological application in learning" Hence, the statement is accepted

Table 10 points out that $98.0 \%$ believed that Educational Technology augment the learning performance of the students by providing them confidence. However, $2.0 \%$ of the respondents have disagreed. $1.0 \%$ was uncertain. The mean score 4.4 falls in the level of agreement which supported the statement 'Educational Technology helps to increase student's overall academic performance and confidence level'. Hence, the statement is accepted.

Table 11 points out that $96.0 \%$ have said that the habits of the students are changing due to Educational Technology while $1.0 \%$ has disagreed. $3.0 \%$ was undecided. The mean score 4.4 falls in the level of agreement which supported the statement Educational Technology is playing a leading role changing the study habits of the students. Hence, the statement is accepted.

Table 12 demonstrates that $84.0 \%$ have the opinion that Educational Technology is increasing day by day while $12.0 \%$ have disagreed. $4.0 \%$ was uncertain. The mean score 4.0 falls in the level of agreement which supported the statement "The use of Educational Technology is increasing day by day at your Institution" Hence, the statement is accepted.

On open ended question responses received from the respondents as: Teachers should be provided training and they should use tools of Educational Technology more frequently $26 \%$ favored the statement, Educational Technology should be promoted. 21\%, Educational Technology increases students learning capabilities $16 \%$, More facilities should be provided to students in terms of access to tools of Educational Technology 15\%, Lectures should be taught through the tools of Educational Technology 11\%, Surdents should be provided training on how to use Educational Technology $11 \%$

\section{B. Analysis, Data Questionnaire from Teachers}

Summary of the sample

\begin{tabular}{|l|l|l|l|l|}
\hline Population & Sample & Delivered & Received & $\%$ Questionnaire Returned \\
\hline 97 & 97 & 97 & 94 & $97 \%$ \\
\hline
\end{tabular}

\begin{tabular}{|c|c|c|c|}
\hline \multicolumn{4}{|c|}{ Teachers Responses } \\
\hline S.No & Item & Yes & No \\
\hline 1 & Is Educationnel Technology being taught in your study Programme? & $\begin{array}{l}93.0 \% \\
(87)\end{array}$ & $\begin{array}{l}7 \% \\
(07)\end{array}$ \\
\hline 2 & Is a white- board placed in your class room? & $\begin{array}{l}86.0 \% \\
(81)\end{array}$ & $\begin{array}{l}14 \% \\
\text { (13) }\end{array}$ \\
\hline 3 & Is multimedia used while delivering lectures in your Institution? & $\begin{array}{l}95 \% \\
(89)\end{array}$ & $\begin{array}{l}5 \% \\
(5)\end{array}$ \\
\hline 4 & Are you able to work with MS office? & $\begin{array}{l}99 \% \\
(93)\end{array}$ & $\begin{array}{l}1 \% \\
(1)\end{array}$ \\
\hline 5 & Can you use internet in order to prepare a lecture? & $\begin{array}{l}95 \% \\
(89)\end{array}$ & $\begin{array}{l}5 \% \\
(5)\end{array}$ \\
\hline 6 & Have you ever attended a training regarding the use of ET tool? & $\begin{array}{l}85 \% \\
(80)\end{array}$ & $\begin{array}{l}15 \% \\
(14)\end{array}$ \\
\hline 7 & Are you provided with audio-visual aids facilities for classroom teaching? & $\begin{array}{l}93 \% \\
(87)\end{array}$ & $\begin{array}{l}7 \% \\
(7)\end{array}$ \\
\hline 8 & Is a printer attached with your computer in the office? & $\begin{array}{l}85 \% \\
(80)\end{array}$ & $\begin{array}{l}15 \% \\
(14)\end{array}$ \\
\hline
\end{tabular}

Table 1 illustrates that $93.0 \%$ are in agreed with the statement while $7.0 \%$ was disagreed. Hence, the statement 'Is Educational Technology being taught in your study programme" is accepted

Table 2 mentioned shows that $86.0 \%$ were favored while $6.0 \%$ were not in the favor of the statement. Hence, the statement 'Is a white -board placed in your class room? 'is accepted.

Table 3 illustrates that $95.0 \%$ supported while $2.0 \%$ were not supported. Hence, the statement 'Is multimedia used while delivering lectures in your institution?' is accepted. 
Table 4 demonstrates that $99 \%$ respondents supported while $1 \%$ were not familiar with it. Hence, the statement 'Are you able to work with MS office?' Was strongly accepted.

Table 5 indicates that $95 \%$ respondents supported the statement while $5 \%$ were disagreed. Hence, the statement 'Can you use internet in order to prepare a lecture? 'Was strongly accepted

Table 6 illustrates that a huge majority of $85 \%$ agreed while only $7 \%$ were disagreed. Hence, the statement Are you provided with audio-visual aids facilities for classroom teaching? was accepted.

Table 8 demonstrates that $85 \%$ of the respondents supported while $15 \%$ were not supported Hence, the statement 'Is a printer attached with your computer in the office?' was accepted.

\begin{tabular}{|c|c|c|c|c|c|c|c|}
\hline No & Statement & SA & $\mathrm{A}$ & UNC & $\mathrm{DA}$ & SDA & M. Score \\
\hline 1 & $\begin{array}{l}\text { Well integration of contents and Educational } \\
\text { Technology tools are promoting the conceptual } \\
\text { learning }\end{array}$ & 27 & 65 & 1 & - & 1 & 4.1 \\
\hline 2 & $\begin{array}{l}\text { Educational Technology is usually used in } \\
\text { achieving the cognitive objectives of the content }\end{array}$ & 39 & 51 & - & 2 & 2 & 4.2 \\
\hline 3 & $\begin{array}{l}\text { Tools of Educational Technology are applied to } \\
\text { achieve the affective domain of each lesson. }\end{array}$ & 33 & 56 & 3 & - & 2 & 4.2 \\
\hline 4 & $\begin{array}{l}\text { Educational Technology is always considered } \\
\text { significantly in achieving psychomotor domain of } \\
\text { the lesson. }\end{array}$ & 47 & 43 & 2 & 1 & 1 & 4.3 \\
\hline 5 & $\begin{array}{l}\text { The use of Educational Technology is increasing } \\
\text { day by day at your Institution }\end{array}$ & 36 & 50 & 2 & 3 & 3 & 4.1 \\
\hline 6 & $\begin{array}{l}\text { Maximum provisions are provided for the use of } \\
\text { Educational Technology in the institution }\end{array}$ & 10 & 79 & 3 & 1 & 1 & 4.0 \\
\hline 7 & $\begin{array}{l}\text { Modern trends of the Educational Technology are } \\
\text { also applied in the institution. }\end{array}$ & 11 & 68 & 11 & 1 & 3 & 3.9 \\
\hline 08 & $\begin{array}{l}\text { Maximum opportunities are provided to the pupil } \\
\text { teachers in the use of tools of Educational } \\
\text { Technology. }\end{array}$ & 17 & 70 & 3 & 2 & 2 & 4.0 \\
\hline 09 & $\begin{array}{l}\text { Educational Technology helps in increasing } \\
\text { confidence level of the students }\end{array}$ & 22 & 70 & 2 & - & - & 4.2 \\
\hline 10 & $\begin{array}{l}\text { The use of Educational Technology helps in } \\
\text { increasing the interest and motivation of the } \\
\text { students }\end{array}$ & 37 & 52 & 2 & 1 & 2 & 4.2 \\
\hline 11 & $\begin{array}{l}\text { The use of Educational Technology is improving } \\
\text { the scientific approach and technological } \\
\text { application in learning }\end{array}$ & 47 & 44 & 2 & - & 1 & 4.3 \\
\hline 12 & $\begin{array}{l}\text { Educational Technology increases student's } \\
\text { overall academic performance }\end{array}$ & 51 & 40 & - & - & 3 & 4.3 \\
\hline 13 & $\begin{array}{l}\text { Educational Technology is playing a leading role } \\
\text { in changing the study habits of the students }\end{array}$ & 45 & 44 & 3 & 1 & 1 & 4.3 \\
\hline 14 & $\begin{array}{l}\text { Proper training in the use of tools of Educational } \\
\text { Technology is provided by the Institution time to } \\
\text { time }\end{array}$ & 8 & 67 & 4 & 13 & 2 & 3.7 \\
\hline 15 & $\begin{array}{l}\text { Teachers face various problems by the } \\
\text { administration in the use of Educational } \\
\text { Technology }\end{array}$ & 10 & 28 & 10 & 37 & 9 & 2.9 \\
\hline 16 & $\begin{array}{l}\text { In future, the use of Educational Technology will } \\
\text { be more utilized in teacher training Institutions }\end{array}$ & 28 & 63 & 1 & 3 & - & 4.2 \\
\hline
\end{tabular}

Table 1 indicates that $98.0 \%$ said that Educational Technology helps in conceptual learning while $1.0 \%$ has disagreed. $1.0 \%$ was undecided. The mean score 4.1 falls in the level of agreement which supported the statement 'Well integration of contents and Educational Technology tools are promoting conceptual learning'. Hence, the statement is accepted.

Table 2 Illustrated that a majority of $96.0 \%$ agreed while only $4.0 \%$ were disagree. The mean score 4.2 falls in the range of agreement which supported the statement 'Educational Technology is usually used in achieving the cognitive objectives of the content'. Hence, the statement is accepted.

Table 3 mentions that $95.0 \%$ of the respondents thought that Educational Technology has the capability to affect the affective domain of the lessons while only $2.0 \%$ have not shared the same opinion. $3.0 \%$ was undecided. The mean score 4.2 falls in the level of agreement which supported the statement hence, the statement is accepted.

Table 4 indicates that $96.0 \%$ have agreed that Educational Technology helps in achieving the psychomotor domain of the lessons. However, $2.0 \%$ have disagreed with this statement. $2.0 \%$ was uncertain. The mean score 4.3 falls in the range of agreement which supported the statement 'Educational Technology is always considered significantly in achieving psychomotor domain of the lesson.' Hence, the statement is accepted.

Table 5 mentioned demonstrates that $92.0 \%$ of the teachers were of the view that Educational Technology is used increasingly while 6.0 were not agreed. $2.0 \%$ was undecided. The mean score 4.1 falls in the range of agreement which supported the statement "The use of Educational Technology is increasing day by day at your Institution" Hence, the statement is accepted. 
Table 6 indicates that $95.0 \%$ of the teachers accepted that they were provided provisions for incorporating Educational Technology in their lectures. $2.0 \%$ however have disagreed. 3.0\% was uncertain. The mean score 4.0 falls in the level of agreement which supported the statement 'Maximum provisions are provided for the use of Educational Technology in the institution'. Hence, the statement is accepted.

Table 7 indicated that $80 \%$ respondents were agreed and only $4 \%$ disagreed with the statement "Modern trends of the educational technology are also supplied in the institution" while the mean score fall in the level of agreed. The statement mostly accepted.

Table 8 states that nearly $85 \%$ respondents were agreed and only $4 \%$ disagreed while the mean score fall in the level of agreed. Hence the statement accepted from the respondents.

Table 9 indicates that $84.0 \%$ have agreed that the tools of Educational Technology are incorporated in teaching at their Institute while $4.0 \%$ did not share the same view. $12.0 \%$ was uncertain. The mean score 3.9 falls in the range of agreement which supported the statement 'Modern trends of the Educational Technology are also applied in the institution. 'Hence, the statement is accepted

Table 10 illustrates that $93.0 \%$ have agreed that teachers and students were encouraged to use the tools of Educational Technology while $4.0 \%$ have disagreed. $3.0 \%$ were undecided. The mean score 4.0 falls in the level of agreement which supported the statement 'Maximum opportunities are provided to the pupil teachers in the use of tools of Educational Technology.' Hence, the statement is accepted.

Table 11 points out that majority of $98.0 \%$ of the teachers have agreed with the statement while $0 \%$ has disagreed. $2.0 \%$ was undecided. The mean score 4.2 falls in the range of agreement which supported the statement 'Educational Technology helps in increasing confidence level of the students'. Hence, the statement is accepted.

Table 12 Illustrates that $95.0 \%$ have agreed the use of Educational Technology is very useful in increasing the interest and motivation of the students. $3.0 \%$ have disagreed $2.0 \%$ was uncertain. The mean score 4.2 falls in the range of agreement which supported the statement 'The use of Educational Technology helps in increasing the interest and motivation of the students '. Hence, the statement is accepted.

Table 13 mentions that $97.0 \%$ of the teachers thought that Educational Technology helps in advancing the scientific approach. Only $1.0 \%$ of the respondents have not shared the same opinion. $2.0 \%$ was not sure. The mean score 4.3 falls in the level of agreement which supported the statement 'The use of Educational Technology is improving the scientific approach and technological application in learning'. Hence, the statement is accepted.

Table 14 indicates that $97.0 \%$ have agreed that Educational Technology helps in improving the academic performance of the students. 3.0\%, however have disagreed. The mean score 4.3 falls in the level of agreement which supported the statement "Educational Technology increases student's overall academic performance" Hence, the statement is accepted.

Table 15 indicates that $95.0 \%$ believed that Educational Technology changes the way in which students learn while only $2.0 \%$ have disagreed. $3.0 \%$ was undecided. The mean score 4.3 falls in the level of agreement which supported the statement "Educational Technology is playing a leading role in changing the study habits of the students" Hence, the statement is accepted.

Table: 16 States that $89 \%$ were agreed and nobody was disagreed while the mean score was 4.2 in the level of agreed Hence, the statement is accepted.

Réponses recieved from the respondents through open ended questions as: The use of Educational Technology maximizes learning35\%, The use of Educational Technology should be promoted 21\%, More facilities regarding the availability of Educational Technology tools should be provided 19\%, Teacher Training Programs should be provided more often $16 \%$.

\section{SUMMARY}

The current study was designed to investigate the use of Educational Technology at Higher Educational Institutions, to evaluate the role of Educational Technology in promoting comprehension learning and to identify the problems in the use of Educational Technology in promoting learning understanding and suggest possible solutions to those problems. The research was limited to two areas i.e. Rawalpindi and Islamabad.

The research showed that Educational Technology is significantly helpful to enhance the comprehension learning and motivation of the students. Modern trends in the use of Educational Technology are being developed rapidly at Higher Educational Institutions. There is a significant increase in application of Educational Technology at Higher Educational Institutions. Educational Technology increases the confidence level of the students. Students stated that they wanted that the teachers should use the modern tools of Educational Technology more often in their lectures as they found lecture method very boring. Students also believed that teachers should be provided training regarding the use of Educational Technology. Students said that more facilities should be provided to students in terms of access to tools of Educational Technology. The teachers were also of the view that more Teaching Training Programs should be provided to them so that they can improve their capability to use the modern tools of Educational Technology.

\section{FINDINGS}


- $98.5 \%$ of the students agreed that Educational Technology helps to improve the learning process.

- $99.0 \%$ were of the view that Educational Technology helps in increasing the comprehension of the students as it facilitates learning.

- $98.0 \%$ indicated that the use of Educational Technology helps in increasing the interest and motivation of the students as the simple lecture method was boring. Students stated that they preferred to learn through the use of multimedia and computer.

- Regarding the nature and features of Educational Technology, a strong majority of $97.0 \%$ was of the view that well integration of contents and Educational Technology tools were promoting the conceptual learning in students.

- Majority of students $(97.0 \%)$ agreed that Educational Technology helped to analyze the characteristics of learning.

- A strong majority of $98.0 \%$ of students thought that Educational Technology helped in improving the cognitive, affective and behavioral type of learning.

- Giving further insight into the nature of Educational Technology, 96.0\% revealed that Educational Technology helped in logical presentation of the Instructional material.

- $84.0 \%$ of the students have agreed that the use of Educational Technology was increasing day by day at their Institution.

- $69.0 \%$ of the students have agreed that mostly teachers are well aware with the use of Educational Technology but there was still room for improvement as teachers should be more trained in the use of the tools of Educational Technology.

- A strong majority of $86.0 \%$ were of the view that they applied modern tools of Educational Technology in their teaching programs.

- A huge majority of $89.0 \%$ agreed that students were encouraged to apply the tools of Educational Technology in their learning.

- $84.0 \%$ of the students told that overhead projector and multimedia were provided to pupil and teacher in practical teaching.

- $84.0 \%$ of the students agreed that mostly the students got training or presentation with the application of Educational Technology how to prepare the lesson.

- $78.0 \%$ of the students stated that students were trained how to select the Educational Technology tools for the contents for making comprehensive quality lesson.

- A strong majority of $96.0 \%$ agreed that Educational Technology was playing very effective role in promoting students confidence.

- $97.0 \%$ of the students were of the view that the use of Educational Technology helps to improve the scientific approach and technological application in learning.

- $96.0 \%$ thought that Educational Technology was playing a leading role changing the study habits of the students.

- $51.0 \%$ of the respondents have pointed out that there was a lack of vision as how to use Educational Technology in teaching.

- $77.0 \%$ of the students have agreed that Tools of Educational Technology were provided sufficiently in the Institution.

- A huge $97.0 \%$ of the students have suggested that adequate use of Educational Technology was the need of the hour at Higher Educational Institutions and Educational Technology should be promoted.

- $86.0 \%$ responded that there was an Educational Technology Resource Centre available at their Institution.

- $63.0 \%$ pointed out that a computer was computer provided to each student in the lab.

- 26.0\% thought that Teachers should be provided training and they should use tools of Educational Technology more frequently.

\section{CONCLUSIONS}

This study proved from respondents that Educational Technology taught as compulsory subject at Master of Arts in Education level in all higher educational institutions. The use of tools of educational technology is being improved day by day. Students and teacher showed their deep interest in the use of educational technology while some problems were shown in the management side to providing the tools for prospective teachers. This study also deducted that students are not get practical training in the use of tools at appropriate level. Hence, there is need to improve the provision of practical application of educational technology tools. Some reservation noted from the students that all teachers are not well qualified in the use of Educational Technology tools. Whereas, the teachers of higher educational institutions suggested that provision of teacher training into the use of educational technology should be provided as changing the modern trends. Research indicated that the use of modern tools help to promote the students confidence and comprehension regarding concept and application of thoughts. It shows the environmental changes effects the students thinking and their study style as well. 
On the basis of the findings and conclusion, the following recommendations are made:

1. The use of Educational Technology should be promoted in the institutions

2. More facilities should be provided to students in terms of access to tools of Educational Technology.

3. Lectures should be taught through the tools of Educational Technology.

4. Students should be provided training on how to use Educational Technology.

5. More facilities regarding the availability of Educational Technology tools should be provided.

6. Teacher Training Programs should be provided more often regarding Educational Technology should be diminished.

7. Effectiveness of Educational Technology depends on teacher teaching skills

8. Seminars should be arranged to highlighting the nature, features, benefits and uses of Educational Technology at Higher Educational Institutions.

9. More computers should be available to the students in the laboratories.

10. Modern trends in the application of Educational Technology should be implemented.

11. Educational Technology is the need of the hour, so should be promoted not only Higher Educational Level but also at Graduates and Under-Graduates Levels.

12. Teachers should be provided training and they should use tools of Educational Technology more frequently

\section{REFERENCES}

[1] Babbie Earl.(1998). The Practice of Social Research $8^{\text {th }}$ Edit International, Thomson Publishing Service Ltd. Baird.

[2] Chickering, A. W., \& Ehrmann, S. C. (1996). implement the seven principles: Technology as lever, San Francisco; AAHE Bulletin

[3] D. E., \& Fisher, M. (2005). Neomillennial user experience design strategies: Utilizing social networking media to support "Always On" learning styles. Journal of Educational Technology Systems, 34 (1), 5-32.

[4] Fox, E. (2005). Tracking U.S trends, Education Week, 24(35) James, R. \& Beattie, K. (1996). Expanding Options: Delivery Technologies and Postgraduate Coursework, Evaluations and Investigations Programme, Department of Employment, Education, Training and Youth Affairs, Canberra; Australian Government Publishing Service.

[5] Hawkins, J., E.M. Panush, \& R. Spielvogel. (1996). National study tour of district technology integration (Summary report), New York: Center for Children and Technology, Education Development Center.

[6] Jarrett, D. (1998). Integrating technology into middle school mathematics: It's just good teaching. Portland, OR; Northwest Regional Educational Laboratory.

[7] MacCan et. Al. (1998). Educational Technology in Higher Education. Retrieved from http://tls.vu.edu.au/learning_and_teaching/guidelines/vu9/educational\%20technology\%20in\%20higher\%20education\%20vu9.p df on 12.05 .11 at 1200

[8] M.O. Education. (2009). National Education Policy 2009. Islamabad, Federal Ministry of Education.

[9] Mukama. E (2008). Information and Communication Technology in Teacher Education: Thinking and learning in computersupported social practice. Ed 1:1. LiU-Tryck: on 14.05.2011 at 1455

[10] Roblyer, Edwards, and Havriluk, M.D., Edwards, Jack, \& Havriluk, Mary Anne. (1997). Integrating Educational Technology into Teaching, Merrill, Upper Saddleriver, NJ.

[11] Rochelle, J.M. Pea, R.D., Hoadley, C.M., Gordin, D.N. and Means, B.M. (2000). Changing how and what children learn in school with computer-based Technologies. USA. The Future of Children, 10:2, Woodrow Wilson School of Public and International Affairs.

[12] Rowntree, D. (1988). Educational Technology in Curriculum Development, London; Harper and Row Ltd.

[13] Russell M. \& Haney W. (1997). Testing Writing on Computers: An Experiment Comparing St Student Performance on Tests Conducted via Computer and via paper and pencil. Retrieved fromhttp://findarticles.com/p/articles/mi_7100/is_4_12/ai_n42544226/ on 6.05.11 at 1500

[14] Waxman, H. C., Connell, M. L., \& Gray, J. (2002). A quantitative synthesis of recent research on the effects of teaching and learning with technology on student outcomes. Naperville, IL: North Central Regional Educational Laboratory.

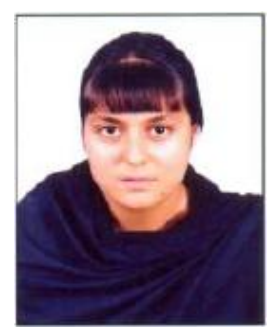

Samira Shah is M.Phil Research Scholar in the department of Education Preston University Islamabad, Pakistan. She received her Master of Arts in Psychology from University of the Punjab, Lahore. She is much interested in research and development of Educational Psychology. 


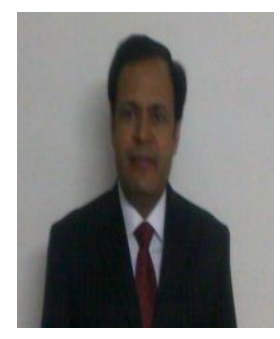

Ali Murtaza is working as Assistant Professor, Institute of Education, University of Azad Jammu \& Kashmir, Muzaffarabad. He received his Ph.D. (Education) from UIER, University of Arid Agriculture Rawalpindi, Pakistan and M.Phil (Education) from Allama Iqbal Open University, Islamabad. Pakistan. He wrote two books and several research articles. He is particularly interested in teachers training, practical teaching and educational research. He is Approved Ph.D Supervisor of Social Sciences by the Higher Education Commission of Pakistan. (HEC) 